\title{
An Analysis of the Characteristics of Maize Storage Types Used by Smallholder Producers in Developing Countries: A Case of Uganda
}

\author{
Tibaingana Anthony1, Godswill Makombe ${ }^{2}$, Tumo Kele² \\ ${ }^{1}$ Makerere University, College of Business and Management Sciences, Kampala, Uganda \\ ${ }^{2}$ Gordon Institute of Business Science, University of Pretoria, Pretoria, South Africa \\ Email: atibaingana@gmail.com,makombeg@yahoo.com, kelet@gibs.co.za
}

How to cite this paper: Anthony, T., Makombe, G. and Kele, T. (2019) An Analysis of the Characteristics of Maize Storage Types Used by Smallholder Producers in Developing Countries: A Case of Uganda. American Journal of Industrial and Business Management, 9, 1524-1555.

https://doi.org/10.4236/ajibm.2019.96101

Received: April 28, 2019

Accepted: June 27, 2019

Published: June 30, 2019

Copyright $\odot 2019$ by author(s) and Scientific Research Publishing Inc. This work is licensed under the Creative Commons Attribution International License (CC BY 4.0).

http://creativecommons.org/licenses/by/4.0/

(c) (i) Open Access

\begin{abstract}
Smallholder maize farmers are often faced with storage challenges. In Ugan$\mathrm{da}$, smallholder farmers are the major producers of maize. After production, the majority sell most of the maize then later buy for consumption at higher prices. This puzzle of producing, selling and later buying for consumption is attributed to inadequate and inefficient storage and is the premise of this investigation. The knowledge of the impact of household storage and farmers' perception in Uganda is limited. The study sought to assess whether the storage types used are associated with the smallholder farmers' characteristics. A multi-stage random sampling procedure was used to collect cross-sectional data from 270 farmers. The region of Eastern Uganda was selected because it is the highest maize producing. Three districts were selected on the basis of being the highest, medium and lowest maize producers, respectively. The chi-square tests were used to check for the relationships between the variables measured at $95 \%$ confidence level $(\mathrm{p}<0.05)$. The findings show a significant relationship of location (district), gender, length of use of a particular storage type, method of acquisition of a storage type used by smallholder maize farmers. Areas of future research and recommendations based on the study findings are presented in the conclusion section.
\end{abstract}

\section{Keywords}

Developing Countries, Maize, Storage Types, Smallholders, Income Security, Food Security

\section{Introduction}

The main aim of maize storage is to ensure it is available all the time and to fulfil cuson in volume, safety and quality [1]. Maize is an important source of food 
fotomer satisfactir millions of people in Africa [2]. It provides food and income to smallholder farmers [3]. Smallholders are "those farmers who produce on a small-scale, not involved in large commercial agriculture but produce for subsistence level, and cultivate less than five hectares of land annually on average [4]. In Sub-Saharan Africa (SSA) agriculture is important because $70 \%$ of its populace depends on agriculture for income and food security [1].

In Uganda, maize is a staple food for majority [5] [6], mainly produced by smallholder farmers. In 2011 maize accounted for 19\% of the total land area under food crops [7]. Maize provides income to the majority of smallholder farmers especially in Eastern Uganda where it is the most traded crop [8]. It also provides food to institutions like schools, hospitals, police, prison and the army [6] [9]. Maize is a seasonal crop [10], so its demand is throughout the year.

In Uganda on farm postharvest grain loss of maize is about $6 \%$ of the quantity stored and increases in some situation to $100 \%$ [11]. Moreover, maize is a large foreign exchange earner for Uganda [12]. Maize is third grown crop after banana and cassava and is grown in all parts of the country ipso facto its importance in the Ugandan economy has increased [13]. In Uganda like many other SSA countries smallholder farmers still used rudimentary tools to store. This unfortunately affects the quality and quantity of the maize produced [14]. Hence a good storage process is required to keep it for future use [15].

It is estimated that about one-third of the food produced globally is wasted in post-harvest handling and storage [16]. Wastage in store reduces the quantity and quality of maize which consequently impacts the income and food security of smallholders [17]. Storage challenges at household level are ubiquitous in developing economies and constitute one of the biggest challenges to household income and food security [18]. Researchers agree that storage of maize grain is still a challenge to many smallholder farmers in SSA [1] [19] [20] [21] [22]. The storage challenge brings about the economic loss for which remedies need to be investigated.

In SSA alone, the value of all grain loss annually is about USD $\$ 4$ billion [16]. Losses of grain occur at five different stages, namely; harvesting, storage, processing, distribution and marketing, and consumption [23]. These authors estimate the food loss associated with post-harvest handling and storage at 32\% globally and 37\% in SSA. Generally in Africa, losses are estimated at between 20 and 40 percent. Almost 1.6 billion per year, nearly $13.5 \%$ of the total value of the grain production is lost in Eastern and Southern Africa alone [1]. [10] found that postharvest loss for maize in Africa ranges between 14\% - 36\% while on-farm storage losses are estimated at $4 \%-10 \%$ of the maize crop. The high losses in storage in SSA are a result of many smallholder maize farmers using traditional storage types [10] [23]. Poor storage management processes at the household level is also a leading cause of losses for smallholder maize farmers. These losses depends on a number of factors including; manual processing, storage types which are permeable to oxygen and moisture, especially floor storage, weather, storage length, pests, hand harvesting, head-load transportation, lack of 
information about proper harvesting and handling methods and other smallholder socio-economic characteristics such as education level [1].

Maize is a vital staple crop in SSA grown by about $86 \%$ of the 4.2 million agricultural households [6]. It is also a centre-piece of economic wellbeing for more than 32 million people in SSA [24]. This study, therefore, focuses only on maize storage because loss in storage is a potential threat to smallholder maize producers' food and income security. Various scientists' indicate that storage plays an important role in the maize transaction and that losses are eminent where storage is poor and as a result, maize damaged during storage does not go to the market and ends up not recorded in the economic transactions [3]. It is important to note that once the maize is damaged in storage, it is bought at low price which, not only affects the overall income, but also denies the farmers maize for consumption thus increasing food insecurity [3] [18].

Smallholder farmers in Uganda sell maize as a residual decision after their consumption needs are met. Despite the scale limitations, smallholder farmers are considered as a vehicle for achieving economic development in rural areas of developing economies [25]. The majority of smallholder farmers earn income after selling their agricultural produce [26]. Smallholder farmers tend to be labour-intensive and grow their maize for three major reasons; selling, consuming and seed. Through selling they are able to circumvent the financial distress by using the proceeds from maize sales. If they are able to store, then they will avoid buying from the market for consumption.

It is worth noting that smallholder maize farmers are usually unable to produce enough for home consumption and market to realise higher incomes [27]. The majority of smallholder farmers use rudimentary tools such as hand-hoes for production and have limited access to markets and new technologies, yet technology, especially that which promotes sustainable agricultural practices, is essential in ensuring continued maize supply [28]. The limited use of modern technology among smallholder farmers in storage is exacerbated by the fact that the majority have not attained a high level of education. This is a major limitation to their contribution as a vital artery of food production [29]. The unregulated temperature conditions in the houses lead to significant maize storage losses [23].

In Uganda, even though it is sold residually, maize is a key source of income for smallholder farmers [18]. It is of high national importance as a major contributor to food and income security at household level while also contributing to export earnings [30]. Eighty-five percent of smallholder maize farmers in Uganda are rural-based and live under impoverished conditions (Uganda Bureau of statistics Statistical Abstract, 2014). Moreover, out of the $13.9 \%$ of the working population in Uganda $72 \%$ is engaged in agriculture (Ibid). Hence, agriculture contributes significantly to the economic wellbeing of smallholder maize farmers. The majority of the farmers are accommodated in grass-thatched huts where they sometimes share space with their domesticated animals and birds. At the same time the huts are sometimes used as storage for 
their produce.

Uganda's population is estimated at 34.9 million. It has increased by 25.3 million between 1969 and 2014 (National Population and Housing Census, 2014). Such population growth results in increased food demand and the demand can be met by increasing maize production. However, the production effort can be assisted through improved storage. The importance of maize among smallholders cannot be over emphasized as earlier mentioned. Besides food and income, it also provides employment to majority of the rural people [30].

Therefore, farmers not only have to store maize for food, and income but they also have to attempt to guard against price fluctuations [10]. Despite the growing demand for maize, smallholders have continued to face serious storage challenges. And yet inadequacy of storage is one of the causes of maize loss among smallholder farmers in Uganda [6]. This loss merits investigation to find out how household characteristics influence the storage types used and their effectiveness.

From a business perspective, when storage is poor (unsafe), both quality and quantity of the maize grain will be affected thereby making the maize less competitive in the market [31]. [32] posited that storage is significant in managing price risk. However, when storage is of poor quality such that it cannot protect both quality and quantity of the maize grain, the farmer is forced to sell immediately after harvest at a low price to avoid future losses [33]. Therefore this study aimed to identify and characterise the different storage types used by smallholder maize farmers in Uganda.

\subsection{Economic Effect of Maize Storage on Smallholder Farmers in Uganda}

Due to seasonality of production, which results in supply fluctuations [10], storage is one way not only to ensure continuous supply, but also to preclude escalating prices. In Uganda, like most of the SSA countries, maize is still largely stored in traditional storage types [3] [34]. Although sacks are becoming increasingly popular, smallholder farmers still store maize in various traditional storage types, including granaries, (open and closed) cribs, baskets, above the fire, clay pots, house roofs, and house corners. These traditional storage types hardly protect the maize from damage [34]. Consequently, smallholder farmers have difficulty in using storage to keep maize from one season to another due to poor storage. Good household level storage is, therefore, critical for smallholder maize farmers to ensure continued supply of maize and better food and income security at household level [1] [10] [34].

[35] argued that good maize storage is not only important for food and income security, but also for seed [36]. Although, metal silos have been proved to be effective in preventing pest damage, many smallholders in Uganda are not aware of this storage technology. In a study in Tanzania, [1] also found out that farmers were not aware of the silo technology. Those who are aware of the metal silo maize storage technology in Uganda cannot afford it [21]. Likewise [11] also 
asserted that lack of capital is a major hindrance to farmer's adoption of such technology. Even though agricultural modernization has been one of the key issues on the economic agenda of the government of Uganda's Vision 2040, little effort has been focused on grain storage improvement, especially for an important crop like maize.

Whereas there are a number of studies conducted in agriculture and smallholder farming in Uganda, much of the focus has been on increasing productivity with limited or no attention directed to household maize storage. Besides, even where storage is mentioned, it is usually about the total post-harvest losses at community level again with minimal attention given to household level storage [3]. [1] mentioned that "However, the financing and actual institutionalization of post-harvest storage and loss prevention strategies are still negligible compared to primary production-related activities" (pp 50). This actually obstructs the effective realisation of the benefits of efforts to increase production.

Consequently, many smallholder maize farmers in Uganda face severe storage challenges compelling them to sell maize immediately after harvest. When they sell immediately after harvest, they are paid low prices due to glut in supply [11].

Since smallholder maize farmers are the key producers of maize in Uganda as earlier mentioned [6] and given that they experience storage challenges, we argue that the storage types used have a significant effect on their food and income security. We aim to identify the different storage types used by smallholder farmers and household characteristics that influence the storage types used and smallholder farmers. The central thesis of this study is that little is known about household storage types used in developing economies, especially in Uganda.

\subsection{Theoretical Foundation}

This study is based on [37] theory of storage and as applied by [38], and Brennan [39]. It states that a holder of stock receives benefits called "convenience yield" which declines as stock, increases [40]. [41] advanced two major assumptions of the theory of storage, namely: "Holders of inventories receive implicit benefits called convenience yield and commodity producers and inventory holders hedge future spot price risk by taking short positions in future market". According to [31], the theory of storage states that a commodity price increases in times of low inventory and decreases when inventory is high. It further indicates that, for seasonal production like maize, storage eases production deficiencies on the key assumption that stored commodities remain safe from damage and deterioration.

Thus, storage has the potential to keep the inventories safe and to maintain continuous supply [42]. Consequently, storage plays a crucial role in price formation [43]. The theory of storage is pivotal in building an understanding of this study. It emphasizes the importance of storage and assumes that good performance of storage yields consistent results. However, this may not be the case with smallholder maize farmers in Uganda. The assumption of standard storage performance does not recognize the fact that traditional storage types used by 
smallholder maize farmers in developing economies, such as Uganda, may not perform at the assumed level. In comparative terms, storage types and their effectiveness are different in developed and developing economies. For example, whereas regulation of storage temperatures through automation is the approach frequently used in developed economies, this is not the case in developing economies, especially for smallholder farmers storing at household level in poor rural settings.

\section{Material and Method}

For better investigation of the smallholder farmers' maize storage perspective and constraints in Uganda, the eastern region was selected through stratified sampling. Stratified sampling was used because of the existing administrative strata in Uganda: eastern, western northern and southern. Within the strata the eastern was the highest maize producing region in Uganda (Uganda agricultural census, 2008/2009). In 2010 the eastern region accounted for over 50\% of annual national production [44]. Cross-sectional data collected through a survey using a semi-structured individual questionnaire using a methodology described by [45].

In the district there are strata of sub-counties and in the sub-counties villages. Multistage simple random sampling was used to select the districts, sub-counties and villages. We first looked at amount of maize produced to come up with a category of high, medium and low. At the first stage, the agricultural census of 2008/2009 was used to select the eastern region of Uganda. In the agricultural census report, the region is referred to as food basket because it is the highest maize producing region in the country. These districts were selected deliberately on the basis of their maize production levels, resting on the assumptions that demand for storage is also a function of levels of production within the selected Eastern Region. The highest and lowest maize-producing districts were selected easily, while the medium-producing district was selected by choosing the district whose production was closest to the average production of all the districts in the region. The highest, medium and lowest producing districts were identified as Iganga, Manafwa and Katakwi respectively.

The second stage of site selection was to select three sub-counties from each district, also based on the high, medium and low selection procedure described above for districts. At the third stage, a simple random sample of three villages was selected from each sub-county making a total of 27 villages. In each village farmers for interview were selected using simple random sampling. A total sample of 270 was interviewed, 30 farmers from each sub-county, ten from each village. The characteristics of these farmers were similar, but they operated at different levels of maize production. For all these simple random selection processes, the SPSS random number generator was used. Although the size of the sample was budget constrained, this number was deemed to be large enough to allow statistical inferences to be drawn. However, in their absence, any adult in the household with knowledge of maize storage was interviewed. Data were 
collected using a structured questionnaire administered by research assistants. Before administering the semi-structured questionnaire drawn it was first pretested to a smaller sample with similar characteristics. Every interview began with the research assistant confirming that the respondent; was a household head or is responsible for maize storage in the household and explaining the aim of the study. Where the respondent was absent in the home the appointment was rescheduled. The information sought was on household characteristics, storage types, used length of storage, reasons for storing and constraints impeding storage. Each interview was designed to last for not more than 40 minutes. Although Uganda has bimodal rainfall resulting in two maize growing seasons, in the study only one season, the second season of 2014/15, was surveyed. The data were collected one season after the 2014/2015 harvest.

Data collected were analysed using SPSS version 21 where descriptive, frequencies, means, ANOVA and Post-hoc analysis were done. The findings are reported and presented in tables and figure as shown in subsequent sections.

\section{Results}

This section presents the distribution of respondents with different socio-demographic characteristics across their levels of maize production. Table 1 summarizes the results of questions concerning the socio-demographic characteristics of smallholder maize farmers in the quantitative sample, and the commentary discusses the relationship of these characteristics to other aspects of storage investigated, such as decision-making roles.

In terms of gender, the sample comprised 44 percent of females and 66 percent males. In the high maize-growing district of Iganga, women, at 64 percent, comprised the majority of smallholder maize growers. The proximity of Iganga to big towns such as Jinja and Kampala creates a trading opportunity, and men are mostly engaged in this activity. By contrast, in the medium- and low-producing districts of Manafwa and Katakwi, agriculture is a male-dominated activity.

However, gender did not coincide with decision-making power over maize storage types, although being a household head did. Only twenty percent of female farmers were household heads, and household heads in general made the decision about which storage type to use ( 50 percent) because the financial importance of maize in households makes it a crop whose disposition males decide. However, there were cases where decisions were either reached jointly by household head and spouse ( 39 percent). In such cases there was a high degree of working together right from planting through to storage which increased cohesion, and the decision to sell was also agreed upon collectively. There were limited circumstances, where a spouse made the decision alone (12 percent). This was most prevalent where the men were either salary earners or solely farmers, or elderly, or where everyone in a household was producing maize individually.

The average age of smallholder maize farmers was 41 years, spread between a minimum age of 16 and a maximum age of 90 . The high and low maize-producing 
Table 1. Distribution of socio-demographic characteristics of respondents (\%).

\begin{tabular}{|c|c|c|c|c|}
\hline \multirow[b]{2}{*}{ Household characteristics } & \multicolumn{4}{|c|}{ District and Production Level } \\
\hline & $\begin{array}{c}\text { IGANGA } \\
\text { High } \\
\text { n }=90\end{array}$ & $\begin{array}{l}\text { MANAFWA } \\
\text { Medium } \\
\text { n }=90\end{array}$ & $\begin{array}{c}\text { KATAKWI } \\
\begin{array}{c}\text { Low } \\
\mathrm{n}=90\end{array}\end{array}$ & $\begin{array}{c}\text { Total } \\
\mathbf{n}=\mathbf{2 7 0}\end{array}$ \\
\hline \multicolumn{5}{|l|}{ Sex } \\
\hline Male & 36 & 69 & 64 & 56 \\
\hline Female & 64 & 31 & 36 & 44 \\
\hline \multicolumn{5}{|l|}{ Age } \\
\hline $16-29$ & 46 & 25 & 49 & 40 \\
\hline $30-49$ & 44 & 64 & 39 & 49 \\
\hline 50 and Above & 10 & 11 & 12 & 11 \\
\hline Mean (standard deviation) & $40(15)$ & $45(14)$ & $40(16)$ & $41(15)$ \\
\hline \multicolumn{5}{|c|}{ Highest level of education attained } \\
\hline None & 12 & 3 & 12 & 9 \\
\hline Primary & 61 & 53 & 43 & 53 \\
\hline Secondary & 26 & 27 & 36 & 29 \\
\hline Tertiary & 1 & 17 & 9 & 9 \\
\hline \multicolumn{5}{|c|}{ Occupation of the household head } \\
\hline Farmer & 96 & 78 & 85 & 86 \\
\hline Salary earner & 0 & 16 & 7 & 7 \\
\hline Trader & 2 & 3 & 3 & 3 \\
\hline Student & 2 & 3 & 4 & 3 \\
\hline Non-response & 0 & 0 & 1 & 0.4 \\
\hline \multicolumn{5}{|c|}{ Number of people in the household } \\
\hline $1-5$ & 24 & 33 & 36 & 31 \\
\hline $6-10$ & 60 & 57 & 48 & 55 \\
\hline Above 10 & 16 & 10 & 16 & 14 \\
\hline Mean (standard deviation) & $7(3)$ & $6(3)$ & $6(3)$ & $6(3)$ \\
\hline \multicolumn{5}{|l|}{ Household structure } \\
\hline Household head & 45 & 76 & 66 & 62 \\
\hline Spouse & 44 & 18 & 18 & 27 \\
\hline Child & 10 & 6 & 12 & 9 \\
\hline Grandchild & 1 & 0 & 3 & 1 \\
\hline Brother & 0 & 0 & 1 & 1 \\
\hline
\end{tabular}

Source: Primary data.

districts demonstrated a similar average age of 40 years; the medium maize-producing district had a slightly higher average age of 45 years.

Across all districts, smallholder maize farmers had, at most, a primary level of 
education with a mean average of seven (standard deviation $=4$ ) years of schooling. The minimum years spent in school was zero; the maximum was 16 years. Likewise, within districts, most respondents had attained only a primary level of education: 61 percent in Iganga and 53 percent in Manafwa, though only 43 percent for Katakwi.

The average number of people in a household was six across sample districts, with Iganga having the highest number at seven members per household, while Katakwi and Manafwa both had an average of six. A household size of six to ten predominated, with this being the size of 60 percent of households in Iganga, followed by 57 percent in Manafwa and 48 percent in Katakwi. High- and low-producing districts showed an equal percentage of households (16 percent) in the household size category of ten and above; the medium-producing district had only ten percent in this category.

To understand the economic situation of the smallholder maize farmers, their occupational status was studied. Overall, an average 86 percent of respondents were engaged solely in smallholder maize farming: 96 percent in Iganga, 78 percent in Manafwa and 85 percent in Katakwi. These figures portray smallholders who are highly dependent on the success of their farms and have no other financial resource to draw on in adapting their storage, or improving household food and income security.

However, some few farmers were also engaged in concurrent additional economic activities. For example, seven percent of respondents were both smallholder maize farmers and salary-earners (16 percent in Manafwa; seven percent in Katakwi; and none in Iganga). The slightly higher percentage of smallholder maize farmers also doubling as salary earners in Manafwa is due to the proximity of the border. Manafwa being near Kenya, it becomes more attractive for those who are employed to also engage in smallholder maize farming, because they are motivated by the availability of a market in Kenya. The remainder were smallholder maize farmers who also engaged in trading (two percent in Iganga; and three percent each in Manafwa and Katakwi), or smallholder maize farmers who were also studying. This reinforces the picture of high dependence on earnings from maize-growing.

\subsection{Maize Growing Characteristics}

Table 2 summarizes the hectarage used to grow maize, the maize yield, and the rates for rented land during the second season of 2014/2015.

The average area of land used for farming in the sampled districts was $1.7 \mathrm{ha}$. It was highest, at 1.9 ha, in Katakwi, followed by Manafwa at 1.6 ha and Iganga at $1.5 \mathrm{ha}$. The average proportion of land used for maize growing was highest in Iganga at 55 percent, followed by Manafwa at 53 percent and Katakwi at 39 percent, underlining the importance of maize in the production system. The average maize yield was highest in Manafwa at $2331 \mathrm{~kg} / \mathrm{ha}$, followed by Iganga at $1752 \mathrm{~kg} / \mathrm{ha}$ and Katakwi at $807 \mathrm{~kg} / \mathrm{ha}$. The triads with other information about 
Table 2. Maize land use and yield by district.

\begin{tabular}{ccccc}
\hline Farming Characteristics & $\begin{array}{c}\text { IGANGA } \\
\text { (High) } \\
\mathbf{n}=\mathbf{9 0}\end{array}$ & $\begin{array}{c}\text { MANAFWA } \\
\text { (Medium) } \\
\mathbf{n}=\mathbf{9 0}\end{array}$ & $\begin{array}{c}\text { KATAKWI } \\
\text { (Low) } \\
\mathbf{n}=\mathbf{9 0}\end{array}$ & $\begin{array}{c}\text { Total } \\
\mathbf{n}=\mathbf{2 7 0}\end{array}$ \\
\hline Total land used for farming in ha & 1.5 & 1.6 & 1.9 & 1.7 \\
Land used for maize growing (in \%) & 55 & 53 & 39 & 48 \\
Maize yield (kg/ha) & 1752 & 2331 & 807 & 1630 \\
Rent amount per ha (UGX) & 77,800 & 163,000 & 94,400 & 111,733 \\
\hline
\end{tabular}

Source: Primary data 1 Exchange Rate: 1 USD $=3300$ Uganda Shilling (UGX) at the time of data collection.

Uganda's average production per hectare, which remains low [46] Comparative figures from the SSA region show production per ha, for example, at $2500 \mathrm{~kg} / \mathrm{ha}$ in South Africa, $1500 \mathrm{~kg} / \mathrm{ha}$ in Nigeria, $5800 \mathrm{~kg} / \mathrm{ha}$ in Mauritius and $7100 \mathrm{~kg} / \mathrm{ha}$ in Egypt (ibid, 2016).

The amount of land allocated to maize was highest among the age group of 30 - 49 years old compared to the elderly who are 50 years old and above. The majority of smallholder maize farmers, 95 percent, were farming land below 1.6 ha; only five percent used land above $2 \mathrm{ha}$. The small hectarage allocated to maize places a limit on increased production and keeps the farmers trapped in food and income insecurity.

Land allocated to maize was acquired through purchase (39 percent), inheritance (40 percent), and rental (15 percent) or as a gift (six percent). In Iganga, 27 percent, 43 percent, 24 percent and 6 percent of smallholder maize farmers, respectively, had purchased, inherited, rented or obtained land as a gift. In Manafwa 34 percent, 50 percent, 11 percent and 5 percent, respectively had purchased, inherited, rented or obtained land as a gift. In Katakwi those who purchased were $57 \%$, inherited were $28 \%$, rented were $10 \%$ and obtained land as a gift were $5 \%$. Overall, smallholder farmers were found to acquire land mainly through two methods: inheritance and purchase. We note, however, that these two acquisition methods are a limitation on the majority of poor smallholders whose families may not have had enough land to inherit, but who also do not have enough money to buy adequate land for maize cultivation.

There is a trend towards renting rather than land ownership, and this is likely to intensify as the population grows, because of the fixed supply of land for agriculture. The findings thus also imply a need for improved access to agricultural land, because the small plots allocated to maize (sometimes as small as 0.4 ha) limit the amount that can be produced.

\subsection{Storage Characteristics}

Smallholder maize farmers used different storage types, reporting on the types they had used for the second harvest season of 2014/2015. Most farmers (62 percent) stored for consumption purposes. Some stored for sale (33 percent) and as seeds for replanting (five percent). Table 3 summarizes the results of the storage types question by district. 
Table 3. Storage type used by district (\%).

\begin{tabular}{ccccc}
\hline Storage types & $\begin{array}{c}\text { IGANGA } \\
(\text { High }) \\
\mathrm{n}=90\end{array}$ & $\begin{array}{c}\text { MANAFWA } \\
(\text { Medium }) \\
\mathrm{n}=90\end{array}$ & $\begin{array}{c}\text { KATAKWI } \\
(\text { Low }) \\
\mathrm{n}=90\end{array}$ & $\begin{array}{c}\text { Average } \\
\mathrm{n}=270\end{array}$ \\
\hline Granary & 0 & 9 & 23 & 11 \\
Crib open & 0 & 0 & 7 & 3 \\
Crib closed & 0 & 3 & 3 & 2 \\
Basket & 0 & 0 & 1 & 0 \\
Above fire & 0 & 0 & 1 & 0 \\
House corner & 10 & 11 & 6 & 9 \\
House roof & 1 & 0 & 1 & 1 \\
Sacks & 89 & 76 & 58 & 74 \\
Total & 100 & 100 & 100 & 100 \\
\hline
\end{tabular}

Source: Primary data.

These results show that across all districts, sacks were the most-used storage type (74 percent); granaries were the second most used storage type at 11 percent, followed by house corners at nine percent. Other storage types such as cribs, baskets, above-the-fire and house roof were minimally used, with baskets, open crib and house roof storage hardly used at all in the high and medium maize producing districts. Between districts, sack usage stood at 89 percent in Iganga, 76 percent in Manafwa and 58 percent in Katakwi. This may be because sacks are readily accessible everywhere.

However, there were other interesting differences between districts. In Katakwi (the low maize-producing area), all eight storage types investigated by the study were used, while in Manafwa (the medium maize-producing area) only four types-house corner, granary, sacks and open cribs-were used. In Iganga (the high maize-producing area), only three storage types-house corner, house roof and sacks-were used.

Some variations in storage type use are easily contextualised. Granaries were used in Manafwa (nine percent) and Katakwi (23 percent) but not in Iganga. In that district, smallholder maize farmers reported that the raw materials for granaries were scarce and thus costly, and that skills also had to be outsourced as farmers lacked the expertise. Farmers more generally reported that baskets were risky compared to sacks because their open tops made them less effective in protecting the maize from pilferage and pest damage.

Additional links between farmers' situation and storage type choice also emerged. Farmers with no education used only three storage types: sacks, house corner and house roof. No female farmers used a closed crib. It was observed that it could be physically challenging to place and remove maize from a closed crib and this may have deterred female smallholder maize farmers from using this method. Besides, cribs were expensive to construct or purchase and the majority of the women could not afford them. Greater diversity of storage types was 
found in the lowest producing district than in the highest. Broadly, the findings demonstrate that the choice of specific individual storage types was based on a far more diverse range of factors, including farmers' location, as well as on the level of maize growing. Two broad categories of storage types (in-house and non-house) were employed as the basis for other questions, and the relationships between these broad categories and other factors are discussed in more depth subsequently.

\subsection{Stored Quantities by Smallholder Maize Farmers}

Maize is stored for three main reasons; for consumption (62\%), to sell later after harvest time at a higher price (33\%) and for seed (five percent). There was a gender difference here: more male smallholder maize farmers (64\%) than female (36\%) stored maize to sell later when prices are high. More male farmers (52\%) also stored for consumption than female farmers (48\%). This interesting finding demonstrates the function of maize as a dual-purpose crop. Male farmers preferred to keep it because they could both consume it in the household and sell when they needed money. Even the maize kept as food would be sold when there was a need for money, in emergency situations for example when a household member is sick.

Using analysis of variance (ANOVA) the means of the quantities of maize stored across districts were compared. In Table 4, the quantity of maize stored by the level of maize production (district) and storage types are presented.

The overall mean stored quantity was $629 \mathrm{~kg}$. The $p$-value of 0.042 shows that there is a significant difference between the three sample districts in the means stored. Smallholder maize farmers in Manafwa stored the highest quantity of maize (916 kg) compared to Iganga and Katakwi with $657 \mathrm{~kg}$ and $313 \mathrm{~kg}$ respectively. Post-hoc analysis was performed to establish the actual groups causing these significant differences. Applying the Tukey test established that the significant difference resulted from the difference between Manafwa and Katakwi districts $(p$-value $=0.032)$, while the other two contrasts between districts were not significant ( $p$-value $>0.05)$.

The average amount of maize stored was $719 \mathrm{~kg}$ (standard deviation $=1756)$ amongst male respondents, and $512 \mathrm{~kg}$ (standard deviation $=1403$ ) amongst female respondents. The difference in quantity stored by gender confirms that maize is more a male-dominated crop because of its commercial nature. Based on ANOVA ( $\mathrm{p}=0.406$ ), it is concluded that this difference between genders in relation to the amount stored is not significant. It was observed that there was a challenge of putting and removing maize from the closed crib whether for consumption or sale ipso facto no female farmer used the closed crib. Also, baskets, open crib and house roof storage types were hardly used in the high and medium maize producing districts due to risks associated and the temporary nature of storage.

Table 5 summarises the results average quantities stored in the various storage types as described below. 
Table 4. Distribution of quantity of maize stored by district $(\mathrm{n}=270)$.

\begin{tabular}{|c|c|c|c|c|}
\hline & \multicolumn{3}{|c|}{ Tukey's HSD } & \multirow{2}{*}{ p-value } \\
\hline District & Mean $(\mathrm{Kg})$ & District & $\mathrm{P}>\mathrm{t}$ & \\
\hline High (Iganga) & 657 & Katakwi vs Iganga & 0.321 & \multirow{4}{*}{0.042} \\
\hline Medium (Manafwa) & 916 & Manafwa vs Iganga & 0.523 & \\
\hline Low (Katakwi) & 313 & Manafwa vs Katakwi & 0.032 & \\
\hline Overall & & 629 & & \\
\hline
\end{tabular}

Source: Primary data.

Table 5. Distribution of quantity of maize stored by storage type $(n=270)$.

\begin{tabular}{ccc}
\hline Storage Type & Sample (n) & Mean Kilogrammes $(\mathrm{kg}) 1$ \\
\hline Granary & 29 & $479(761)$ \\
Crib (open) & 6 & $263(373)$ \\
Crib (closed) & 6 & $2033(1936)$ \\
Basket & 1 & $20(0)$ \\
Above fire & 1 & $2(0)$ \\
House corner & 24 & $1408(4040)$ \\
House roof & 2 & $51(69)$ \\
Sacks & 201 & $538(1134)$ \\
Overall & 270 & $629(1612)$ \\
\hline
\end{tabular}

Source: Primary data 1. Standard deviations in brackets.

The results tabulated above demonstrate how the quantity of maize stored varied between the storage types used. The usage of storage types was not uniform: as noted, the majority of households used sacks, followed distantly by granary and house corner storage. Because of these variations in the use of storage types, the study chose to compare quantities without testing their significances. Overall, household maize storage was $629 \mathrm{~kg}$ (standard deviation = 1612). Of the three most popular storage types, sacks were used for an average of $538 \mathrm{~kg}$ (standard deviation $=1134)$, granaries for $479 \mathrm{~kg}($ standard deviation $=761)$ and house corners for $1408 \mathrm{~kg}$ (standard deviation = 4040). These relatively high standard deviations indicate how wide was the spread of variations in quantity between households employing same storage type and for this reason the researcher decided-given the unknown distributions of quantities stored-that further tests of significance would not yield relevant results.

\subsection{Testing for Association between Storage Type Category and Location (District)}

For this part of the investigation, storage types were categorised into in-house based and non-house based types. The in-house-based storage types comprised sacks, baskets, house corner and above fire; the non-house types comprised gra- 
naries, cribs (open and closed) and house roof. The chi-square, as explained by Allan (1980), was used to test for any association between the storage type categories and the different household characteristics assumed to affect the choice of storage type.

Table 6 summarises the results of the association, using Fisher's exact test given that some cells had less than five percent counts for the association between storage type category and location (district).

The $p$-value of 0.000 shows a significant association between the choice of in-house or non-house storage type by smallholder maize farmers, and their location (represented by district). Although in-house storage types were used in all districts, they were most commonly used in Iganga district (39\%) and Manafwa district (35\%). Across all districts, they were used by $84 \%$ of the smallholder maize farmers in 2014/2015. The non-house storage types, such as open and closed cribs, house roof and granary, accounted for only $16 \%$ of usage, mainly in Katakwi district (72\%).

\subsection{Testing for Association between Storage Type Category and Gender}

The hypothesis that there is an association between the use of these two storage categories and gender was explored. Table 7 summarises the results of the chi-square test for association between storage type category and gender.

The findings in Table 7 demonstrate that there is a significant association between storage type category, and gender. Women in SSA constitute the majority of smallholder farmers (Midegi et al., 2016) and they need to make careful decisions about where to store their maize. Male smallholder maize farmers formed the majority (74\%) of users of the non-house storage type.

The smaller percent of women making use of the non-house storage category was, in part, due to the risks involved, such as theft and cost of storage. Particularly at night, women could not easily guard their maize and preferred to use in-house storage. However, more men than women (53\%) also used in-house storage. The overall dominance of male farmers in both categories of maize storage may be because, besides being a food crop, maize is also a commercial crop, and men tend to dominate commercial activities as earlier mentioned.

Table 6. Testing for association between district and storage type.

\begin{tabular}{|c|c|c|c|c|c|}
\hline \multirow{3}{*}{ District } & \multicolumn{2}{|c|}{ Storage type used } & \multirow{3}{*}{$\begin{array}{l}\text { Total } \\
(\%)\end{array}$} & \multirow{3}{*}{$\mathrm{n}$} & \multirow{3}{*}{$p$-value } \\
\hline & $\begin{array}{c}\text { In-house } \\
\text { (Sacks/house/baskets) }\end{array}$ & $\begin{array}{c}\text { Non-house } \\
\text { Granary/crib }\end{array}$ & & & \\
\hline & $\%$ & $\%$ & & & \\
\hline Iganga & 39 & 2 & 33 & 90 & \multirow{4}{*}{0.000} \\
\hline Manafwa & 35 & 26 & 33 & 90 & \\
\hline Katakwi & 26 & 72 & 33 & 90 & \\
\hline Overall & 84 & 16 & 100 & 270 & \\
\hline
\end{tabular}

Source: Primary data. 
Table 7. Testing for association between gender and storage type used.

\begin{tabular}{|c|c|c|c|c|c|}
\hline \multirow[b]{2}{*}{ Gender } & \multicolumn{2}{|c|}{ Storage type used } & \multirow[b]{2}{*}{$\begin{array}{c}\text { Total } \\
(\%)\end{array}$} & \multirow[b]{2}{*}{$\mathrm{n}$} & \multirow[b]{2}{*}{$p$-value } \\
\hline & $\begin{array}{c}\text { In-house } \\
\text { (Sacks/house/baskets) } \\
(\%)\end{array}$ & $\begin{array}{c}\text { Non-house } \\
\text { (Granary/Crib) } \\
(\%)\end{array}$ & & & \\
\hline Male & 53 & 74 & 56 & 152 & \\
\hline Female & 47 & 26 & 44 & 118 & 0.009 \\
\hline Overall & 100 & 100 & 100 & 270 & \\
\hline
\end{tabular}

Source: Primary data.

In terms of gender differences between districts, the results demonstrate that the majority (66\%) of those using non-house types in Katakwi were male, compared to 34\% in Manafwa and none in Iganga. Non-house storage may be more prevalent in Katakwi because of the nature of houses, which are round and small and may allow insufficient room for in-house storage.

\subsection{Testing for Association between Storage Type Category and Storage Acquisition Method}

Table 8 summarises the results of the chi-square test for association between storage type category and storage acquisition method.

The p-value of 0.000 shows that there is a significant relationship between how a storage type was acquired and its use. Cramer's V of 0.530 shows that the strength of the association is extremely strong from medium to large. The majority, $67 \%$ of smallholder maize farmers in all three districts, had purchased the type of storage they used, across all types, while $31 \%$ had built their own during the second season of 2014/2015. Only two percent had either inherited or been gifted the storage types. Storage at household level is either purchased or made locally. For in-house storage types the pattern is the same: the majority, $77 \%$ of respondents using in-house storage types, had purchased them. Most non-house storage types (84\%) had been constructed by the smallholders who used them. The findings imply that smallholder access to storage type is through purchase and yet the majority are poor hence unable to access better storage type.

\subsection{Association between Storage Types and the Use of Storage over Multiple Seasons}

Table 9 summarises the results of the chi-square test for association between storage type category and multiple seasonal uses of storage.

The $p$-value of 0.032 shows that there is a robust association between storage type category and the use of the same storage type over several seasons. Cramer's $\mathrm{V}$ of 0.160 shows that the strength of association is weak from small to medium. Eighty-seven percent of the smallholder maize farmers in the sample districts reported using the same storage types in "each season" (defined as every time they harvest). Six percent reported using the storage type for one year (past two seasons) and seven percent reported using the storage type for the last season of 
Table 8. Testing for association between acquisition methods and storage category used.

\begin{tabular}{|c|c|c|c|c|c|}
\hline \multirow{2}{*}{$\begin{array}{l}\text { Acquisition of } \\
\text { storage type }\end{array}$} & \multicolumn{2}{|c|}{ Storage type used } & \multirow{2}{*}{$\begin{array}{l}\text { Total } \\
(\%)\end{array}$} & \multirow[b]{2}{*}{$\mathrm{n}$} & \multirow[b]{2}{*}{$p$-value } \\
\hline & $\begin{array}{c}\text { In-house } \\
\text { (Sacks/house/baskets) }\end{array}$ & $\begin{array}{l}\text { Non-house } \\
\text { Granary/crib }\end{array}$ & & & \\
\hline Constructed it & 21 & 84 & 31 & 84 & \multirow{4}{*}{0.000} \\
\hline Purchased & 77 & 14 & 67 & 181 & \\
\hline Others & 2 & 2 & 2 & 5 & \\
\hline Overall & 100 & 100 & 100 & 270 & \\
\hline
\end{tabular}

Source: Primary data.

Table 9. Testing for relationship between use of storage over time and storage category.

\begin{tabular}{|c|c|c|c|c|c|}
\hline \multirow{2}{*}{$\begin{array}{l}\text { Seasonal use of } \\
\text { storage type }\end{array}$} & \multicolumn{2}{|c|}{ Storage type used } & \multirow{2}{*}{$\begin{array}{l}\text { Total } \\
(\%)\end{array}$} & \multirow[b]{2}{*}{$\mathrm{n}$} & \multirow[b]{2}{*}{$p$-value } \\
\hline & $\begin{array}{c}\text { In-house } \\
\text { (Sacks/house/baskets) }\end{array}$ & $\begin{array}{c}\text { Non-house } \\
\text { Granary/crib }\end{array}$ & & & \\
\hline Last season & 7 & 7 & 7 & 19 & \multirow{4}{*}{0.032} \\
\hline Last 2 seasons & 4 & 14 & 6 & 15 & \\
\hline Every season & 89 & 79 & 87 & 236 & \\
\hline Overall & 100 & 100 & 100 & 270 & \\
\hline
\end{tabular}

Source: Primary data.

2014/2015. This demonstrates that there was limited innovation around storage types amongst smallholder maize farmers: the majority adhered to the same storage types.

\subsection{Testing for Association between Storage Type Category and the Decision-Maker in Using a Particular Storage Type}

Table 10 summarises the results of the chi-square test for association between storage type category and the decision maker to use a particular storage type.

Although the findings demonstrate that household heads were the major decision-makers regarding which storage type to use, a p-value of 0.100 . Findings in Table 10 reveal that there is no sufficient evidence to reject the hypothesis that storage type used does not differ by sex of decision maker. In addition, there is no significant association between the decision maker and the storage type used implying that using in-house or non-house storage does not differ based on the whether the household head or the spouse takes the decision. Maize storage was the concern of the person who produced the crop and related to his or her reason for producing it-not necessarily the household head. In households where husband, wife and children each produced individually, even storing it would be an individual decision.

\subsection{Testing for Association between Storage Type Category and Education of the Household Head}

Table 11 summarises the results of the chi-square test for association between storage type category and the education of the household head. 
Table 10. Testing the decision-maker in using a storage type against a given storage category.

\begin{tabular}{cccccc}
\hline \multirow{2}{*}{$\begin{array}{c}\text { Decision maker to } \\
\text { use storage type }\end{array}$} & $\begin{array}{c}\text { In-house } \\
\text { (Sacks/house/baskets) }\end{array}$ & $\begin{array}{c}\text { Non-house } \\
\text { Granary/crib }\end{array}$ & $\begin{array}{c}\text { Total } \\
(\%)\end{array}$ & $\mathrm{n}$ & $p$-value \\
\hline Household head & 50 & 47 & 50 & 134 \\
$\begin{array}{c}\text { Household spouse } \\
\text { Both household } \\
\text { head and spouse }\end{array}$ & 10 & 21 & 12 & 31 & 0.100 \\
Overall & 40 & 33 & 38 & 105 & \\
\hline
\end{tabular}

Source: primary data.

Table 11. Association between education level and storage type used.

\begin{tabular}{cccccc}
\hline $\begin{array}{c}\text { Level of educa- } \\
\text { tion }\end{array}$ & \begin{tabular}{c} 
Storage type used \\
In-house \\
\cline { 2 - 4 } (Sacks/house/baskets)
\end{tabular} & $\begin{array}{c}\text { Non-house } \\
\text { Granary/crib }\end{array}$ & $\begin{array}{c}\text { Total } \\
(\%)\end{array}$ & $\mathrm{n}$ & $p$-value \\
No school & 11 & 2 & 9 & 25 \\
Primary level & 54 & 47 & 53 & 142 & 0.152 \\
Secondary level & 27 & 40 & 29 & 79 & 24 \\
Tertiary level & 8 & 12 & 9 & 24 \\
\hline
\end{tabular}

Source: Primary data.

There was no significant association between the highest level of education of the household head and the storage type category used ( $p$-value $>0.05$ ). This result seems counterintuitive. However, it may relate to the absence of any significant association between the decision maker and the storage type category shown in Table 11 above. Given that finding, it is possible the education of the decision-maker-rather than of the household head-should have been tested against the storage type category, since it was not always the household head who made the decision. Thus perhaps another study could further explore this important relationship.

In summary, therefore, this study showed significant relationships between storage type and four farmer characteristics: location (district), gender, acquisition of storage type and continued use of storage type. No association was found between storage type and two other characteristics: education, and the identity of the decision-maker on storage type.

\subsection{Characteristics of Smallholder Farmers Who Sold Maize}

Since maize is stored for both home consumption and sale, the characteristics of the farmers who sold maize were explored. Smallholder maize farmers were asked whether they sold and/or purchased maize in the second harvest season of 2014/2015. The analysis of different household market characteristics by storage type for the smallholder maize farmers is presented in subsequent sections. 


\subsection{Testing for Association between Maize Selling Characteristics and Storage Type}

Table 12 summarises the results of the chi-square test for association between the maize selling characteristics and storage type of the smallholder farmer.

Sixty-eight percent of all smallholder maize farmers sold maize. Sixty-nine percent of those who sold used the in-house storage category while $31 \%$ used the non-house storage category. However, the findings presented in Table 13 indicate that there is no sufficient evidence to reject the hypotheses that storage type used varies by the amount of maize sold and whether such maize was sold immediately after harvest or stored and sold later. The act of selling maize was not associated with the farmer's storage category. For example, in all the sample districts farmers indicated that whether a smallholder stored in-house or non-house he or she faced the prospect of either incurring a loss or selling immediately (less than one month) after harvest, because both storage categories were equally unsafe. However, the in-house category was preferred because at least the risk of theft was reduced. These findings are also explored in more detail in the table below.

\subsection{Testing for Association between Time of Sale and Storage Type}

Table 13 summarises the results of the chi-square test for association between the time after harvest at which a smallholder chose to sell, and the storage type employed.

The findings show that the time when the farmers sold their maize produce was not significantly associated with the storage category ( $p$-value of 0.734 ). Drawing a summary observation from the chi-square test results in both Table 13 and Table 14, there is no significant association between storage category and a smallholder maize farmers' market pattern, sale of maize or timing of the sale after harvest.

\subsection{Household Characteristics and Storage Length}

This section reports on testing for any association between household characteristics (storage type and category, gender, age, district, household size, hectarage under maize and level of education) and the length of time for which smallholder maize farmers stored maize. The testing employed a one-way analysis of variance (ANOVA). Table 14 summarises the results.

Table 12. Relationship between maize sales pattern and storage type.

\begin{tabular}{ccccccc}
\hline \multirow{2}{*}{ Market characteristics } & \multicolumn{2}{c}{ Storage type used } & Total \\
& \multicolumn{2}{c}{\begin{tabular}{c} 
In-house \\
\cline { 2 - 5 }
\end{tabular}} & $\mathrm{n}$ & Non-house \\
Sacks/house/basket (\%) & $\begin{array}{c}\text { Granary/crib (\%) } \\
\text { Sold maize }\end{array}$ & 69 & 31 & 68 & 183 & 0.263 \\
$\begin{array}{c}\text { Sold immediately after } \\
\text { harvest }\end{array}$ & 46 & 42 & 45 & 83 & 0.736 \\
\hline
\end{tabular}

Source: Primary data. 
Table 13. Association between time of sell and storage type.

\begin{tabular}{ccccccc}
\hline \multirow{2}{*}{ Market characteristics } & \multicolumn{2}{c}{ Storage type used } & & & \\
\cline { 2 - 4 } & $\begin{array}{c}\text { In-house } \\
\text { (Sacks/house/basket) }\end{array}$ & $\begin{array}{c}\text { Non-house } \\
\text { Granary/crib }\end{array}$ & $\begin{array}{c}\text { Total } \\
(\%)\end{array}$ & $\mathrm{n}$ & $p$-value \\
\cline { 2 - 4 } Time period of sell after harvest & $(\%)$ & $(\%)$ & & & \\
\cline { 1 - 4 } Immediately after harvest & 46 & 39 & 45 & 82 & \\
One month & 10 & 15 & 10 & 19 & \\
Two months & 18 & 15 & 18 & 32 & \\
Three months & 9 & 4 & 8 & 15 & 0.734 \\
Four months & 8 & 12 & 9 & 16 & \\
Five months & 10 & 15 & 10 & 19 & \\
\hline
\end{tabular}

Source: Primary data.

Table 14. Relationship between farmer characteristics and storage length $(n=270)$.

\begin{tabular}{cccc}
\hline Farmer characteristics & F-value & $p$-value & Mean length of storage (months) \\
\hline Gender & 0.06 & 0.80 & $1.31(0.55)$ \\
Age & 1.92 & 0.15 & $1.35(0.49)$ \\
District (Location) & 2.50 & 0.08 & $1.31(0.54)$ \\
Number of people in the household & 2.71 & 0.07 & $1.35(0.50)$ \\
Land used for maize growing & 4.29 & 0.01 & $1.32(0.52)$ \\
Level of education & 0.52 & 0.67 & $1.34(0.51)$ \\
Storage type & 2.46 & 0.12 & \\
Overall & & & $1.31(0.55)$ \\
\end{tabular}

Source: Primary data 1. Standard deviation in brackets.

Table 14 shows that the mean storage length for those who sold maize in the second harvest season of 2014/2015 was 1.31 (standard deviation $=0.55$ ) months. Although maize storage is important, the majority of the smallholder maize farmers do not store for long, underscoring the findings above about selling immediately after harvest.

The findings show no significant association between gender, age, district, education level, household size and storage type and the storage length in months of the smallholder maize farmers ( $p$-value $>0.05$ ). The only household characteristic significantly associated with storage length was the hectarage under maize $(p=0.01)$. The more land allocated to maize farming, the greater the likelihood that maize is stored for longer. A larger-scale farmer can produce more maize and has the financial resources to invest in better storage types that can preserve maize for a longer period.

Using land size classification categories of 0.10 - 1.50; 1.51 - 3.00; 3.10 - 5.00; 5.10 and above (in hectare), post-hoc testing using Tukey was done to test for the differences in storage lengths and land area allocated to maize farming in the three sample districts. Table 15 summarises the results. 
Table 15. Contrasts amongst categories of land allocated to maize farming using the Tukey test.

\begin{tabular}{ccccccc}
\hline \multirow{2}{*}{ Maize land (hectare) } & Contrast & \multicolumn{5}{c}{ Tukey } \\
\cline { 3 - 7 } & & $\mathrm{SE}$ & $\mathrm{t}$ & $\mathrm{p}>\mathrm{t}$ & (95\% Conf. Interval) \\
\hline $1.51-3.00$ vs. $0-1.50$ & 0.07 & 0.09 & 0.79 & 0.86 & -0.16 & 0.29 \\
$3.10-5.00$ vs. $0-1.50$ & 0.18 & 0.10 & 1.91 & 0.23 & -0.07 & 0.43 \\
5.1 - Above vs. $0-1.50$ & 0.32 & 0.09 & 3.35 & 0.01 & 0.07 & 0.56 \\
$3.10-5.00$ vs. $1.51-3.00$ & 0.12 & 0.09 & 1.22 & 0.61 & -0.13 & 0.36 \\
$5.1-$ Above vs. $1.51-3.00$ & 0.25 & 0.09 & 2.68 & 0.04 & 0.01 & 0.49 \\
$5.1-$ Above vs. $3.10-5.00$ & 0.13 & 0.10 & 1.30 & 0.56 & -0.13 & 0.39 \\
\hline
\end{tabular}

Source: Primary data.

Further analysis of land allocated to maize farming by the farmer, using the Tukey test, indicates that the significant differences in terms length of storage arises mainly from two categories of land size: 1.5 ha and below, versus 5.1 ha or more; and 1.51 to 3.00 ha versus 5.1 ha or more $(p$-value $=0.01)$.

\subsection{Current Smallholder Farmer Market Behaviour}

The average period in month from storage to sale of maize produce varied among the three districts. In Iganga it was $($ Mean $=2.3$; Standard deviation $=$ 1.6), in Manafwa (Mean $=2.2$; Standard deviation $=1.5)$ and Katakwi Mean = 3.1; Standard deviation $=2.0$ ). Using only the proportion of the sample who sold maize, Table 16 shows that $44 \%$ of those who sold maize, sold immediately after harvest (in less than one month).

Eighteen percent of smallholder farmers sold their maize two months after harvest and very few (ten percent) sold after five month. Fifty-four percent of those sold maize two months after harvest. At that time, prices are usually low because that is the time of highest (glut) supply. As a result, these farmers realise only a small share of the marketing margin. Some of the farmers who sell immediately after harvest later face consumption challenges and have to re-purchase maize from the market. However, the fact that there are farmers who attempt to store so as to sell later (that is, to realise a greater proportion of the maize marketing margin) shows that smallholder maize farmers have some appreciation of the theory of storage.

Also, immediately after harvest (less than a month) farmers who have consumed resources waiting for the maize harvest to mature will face a high demand for cash. This makes it more likely that many, if not all, farmers will sell a portion of their maize immediately after harvest.

Aside from what proportion of farmers stored for longer, it thus becomes important to establish what proportion of farmers would have liked to store for longer, what periods they would have wanted to store for, and what constraints precluded them from doing so. It is equally important to establish whether those 
Table 16. Distribution of farmers who sold maize at different times $(n=183)$.

\begin{tabular}{cc}
\hline Time period of sell & Percentage of farmer who sold at different times \\
\hline Less than a month after harvest & 44 \\
One month after harvest & 10 \\
Two months after harvest & 18 \\
Three months after harvest & 9 \\
Four months after harvest & 9 \\
Five months after harvest & 10 \\
Total & 100 \\
\hline
\end{tabular}

Source: Primary data.

who stored for longer succeeded in storing for time they desired. If not, what constraints precluded them from doing so? These are all areas for further study.

\subsection{Variation in Maize Selling Prices by Period of Storage}

Given that some farmers did store maize and sold later in the season during the second season of 2014/2015, it is important to establish whether the prices realised by that category are higher than those who sold immediately after harvest. Did those who stored maize and sold it later realise a higher share of the maize marketing margin through storage? Figure 1 shows the price variations at different time periods of sale.

Figure 1 shows that when smallholder maize farmers sell immediately after harvest they get UGX 620 per kilogramme. If they store and sell later-for example, after two months-they get UGX 752, and when they store for longer and sell, for example, after four months they receive a higher price of UGX 983. Farmers who stored and sold later realised a higher price (and therefore a higher share of the maize marketing margin) and that price increased over the duration of the storage period. This demonstrates the potential for smallholder maize farmers to increase their share of the maize marketing margin through longer storage.

However, because the smallholder farmers themselves often cannot store, due to constraints (including poor storage performance and high storage costs), this potential margin is instead enjoyed by the traders who buy at low prices from the smallholders immediately after harvest and store only to sell to (some of the same) smallholders later at a higher price, when the smallholders need maize for consumption. The fall in price after five months shown in Figure 1 is a result of the expectation at that point of the new harvest.

From this price analysis, it can be argued that if the ability of smallholder maize farmers to store efficiently is improved, then they can increase their share of the maize marketing margin by storing and selling later at a higher price. Since smallholder maize farmers who purchased maize on average paid UGX 938 per kilogramme, this shows the potential maize marketing margin farmers 


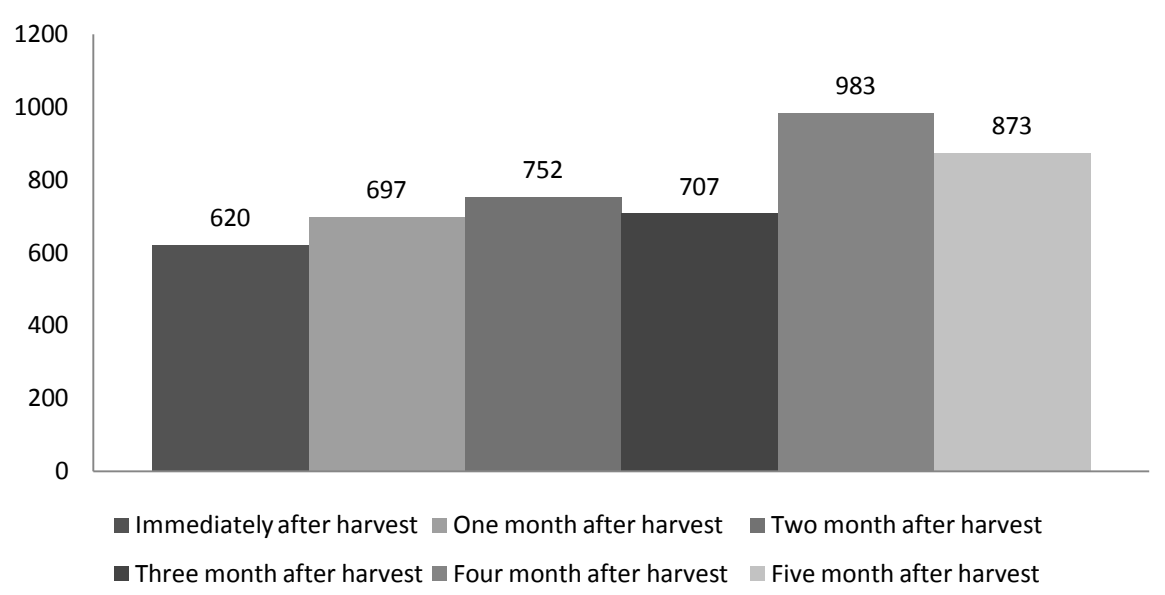

Figure 1. Maize price variation with period of storage 1 Price in UGX is per kilogram.

could realise if they did not sell immediately after harvest for a price of UGX 620. In addition, if smallholder farmers' storage were improved, their ability to store maize securely for longer would obviate the need to purchase maize in later months at higher prices. It is therefore essential to understand what factors may influence both the period of sale and storage length

\subsection{Testing for Association between Period of Sale and Smallholder Farmer's Characteristics}

Table 17 summarises the results of the chi-square test for association between period of sale and farmers characteristics.

The $p$-value of 0.009 shows a significant relationship between when the farmer sells his/her maize and where s/he is located. Farmers near towns sold their maize earlier than those who were distant from the town markets, thus making location an important factor in the transaction. Another factor significantly associated with time of sale ( $p$-value 0.001 ) is the amount of land under maize production. As earlier noted, land is often rented for maize production. Those smallholder maize farmers who rent land would be compelled to sell immediately after harvest to pay rent to the landowners and this may be one component of the association.

The one-way ANOVA p-value of 0.000 shows another significant relationship: between land allocated to maize and time of sale. Post-hoc analysis shows that the more land allocated to maize farming generated more maize production and subsequently more storage length and time of sale. Other characteristics - gender, storage type used, education level and household size - were not significantly associated with time of sale.

\subsection{Analysis of Storage Types by Time of Sale}

Since some farmers store for sale later, it is important to find out if there are any differences in the storage types used by those who store maize for different lengths of periods for sale at different times. Table 18 summarises the results. 
Table 17. Association between periods of sell and farmer characteristics $(n=183)$.

\begin{tabular}{|c|c|c|c|c|c|c|}
\hline \multirow[b]{2}{*}{ Characteristic } & \multicolumn{6}{|c|}{ Time of sale of maize after harvest } \\
\hline & $\begin{array}{c}\text { Immediately } \\
(\%)\end{array}$ & $\begin{array}{l}\text { One month } \\
(\%)\end{array}$ & $\begin{array}{c}\text { Two } \\
\text { months } \\
(\%)\end{array}$ & $\begin{array}{c}\text { Three } \\
\text { months } \\
(\%)\end{array}$ & $\begin{array}{c}\text { Four } \\
\text { months } \\
(\%)\end{array}$ & $\begin{array}{c}\text { Five } \\
\text { months } \\
(\%)\end{array}$ \\
\hline \multicolumn{7}{|c|}{ Age in years } \\
\hline $16-29$ & 40.2 & 47.4 & 40.6 & 33.3 & 37.5 & 36.8 \\
\hline $30-49$ & 56.1 & 47.4 & 46.9 & 60.0 & 50.0 & 31.6 \\
\hline 50 and above & 3.7 & 5.3 & 12.5 & 6.7 & 12.5 & 31.6 \\
\hline \multicolumn{7}{|c|}{ Chi-square $=16.66 ; p$-value $=0.082$} \\
\hline \multicolumn{7}{|c|}{ Gender } \\
\hline Male & 56.1 & 68.4 & 59.4 & 60.0 & 68.8 & 73.7 \\
\hline Female & 43.9 & 31.6 & 40.6 & 40.0 & 31.3 & 26.3 \\
\hline \multicolumn{7}{|c|}{ Chi-square $=3.00 ; p$-value $=0.700$} \\
\hline \multicolumn{7}{|c|}{ District/Location } \\
\hline Iganga & 37.8 & 31.6 & 37.5 & 46.7 & 6.3 & 26.3 \\
\hline Katakwi & 32.9 & 21.1 & 25.0 & 33.3 & 43.8 & 0.0 \\
\hline Manafwa & 29.3 & 47.4 & 37.5 & 20.0 & 50.0 & 73.7 \\
\hline \multicolumn{7}{|c|}{ Chi-square $=23.51 ; p$-value $=0.009$} \\
\hline \multicolumn{7}{|c|}{ Number of people in the household } \\
\hline Small & 32.9 & 26.3 & 25.0 & 26.7 & 62.5 & 31.6 \\
\hline Medium & 56.1 & 63.2 & 53.1 & 60.0 & 31.3 & 36.8 \\
\hline Large & 11.0 & 10.5 & 21.9 & 13.3 & 6.3 & 31.6 \\
\hline \multicolumn{7}{|c|}{ Chi-square $=14.94 ; p$-value $=0.580$} \\
\hline \multicolumn{7}{|c|}{ Amount of land used for maize production (hectare) } \\
\hline Less than 1.5 ha & 31.7 & 26.3 & 15.6 & 6.7 & 18.8 & 21.1 \\
\hline $1.51-3 \mathrm{ha}$ & 34.1 & 36.8 & 25.0 & 40.0 & 18.8 & 36.8 \\
\hline $3.1-5$ ha & 14.6 & 21.1 & 25.0 & 20.0 & 25.0 & 10.5 \\
\hline 5 ha and above & 19.5 & 15.8 & 34.4 & 33.3 & 37.5 & 31.6 \\
\hline \multicolumn{7}{|c|}{ Chi-square $=14.06 ; p$-value $=0.001$} \\
\hline \multicolumn{7}{|c|}{ Level of education } \\
\hline None & 4.9 & 0.0 & 3.1 & 6.7 & 0.0 & 0.0 \\
\hline Primary & 61.0 & 52.6 & 53.1 & 46.7 & 56.3 & 52.6 \\
\hline Secondary & 28.0 & 36.8 & 31.3 & 40.0 & 18.8 & 36.8 \\
\hline Tertiary & 6.1 & 10.5 & 12.5 & 6.7 & 25.0 & 10.5 \\
\hline \multicolumn{7}{|c|}{ Chi-square $=10.79 ; p$-value $=0.767$} \\
\hline \multicolumn{7}{|c|}{ Storage types } \\
\hline In-house & 87.8 & 78.9 & 87.5 & 93.3 & 81.3 & 78.9 \\
\hline Non-house & 12.2 & 21.1 & 12.5 & 6.7 & 18.8 & 21.1 \\
\hline & Chi-squ & $\operatorname{are}=2.78 ; p-v$ & alue $=0.3$ & & & \\
\hline
\end{tabular}

Source: Primary data. 
Table 18. Storage types by time of sale.

\begin{tabular}{|c|c|c|c|c|c|c|c|c|c|}
\hline \multirow[b]{2}{*}{$\begin{array}{c}\text { Storage type } \\
\text { used }\end{array}$} & \multicolumn{7}{|c|}{ Time of sale after harvest } & \multirow[b]{2}{*}{$\begin{array}{c}\text { Total } \\
\mathrm{n}=270\end{array}$} & \multirow[b]{2}{*}{$\begin{array}{c}\text { Total } \\
(\%)\end{array}$} \\
\hline & $\begin{array}{c}\text { Did } \\
\text { not sell } \\
\mathrm{n}=87\end{array}$ & $\begin{array}{l}\text { Immediately } \\
\quad \mathrm{n}=82\end{array}$ & $\begin{array}{c}\text { One } \\
\text { month } \\
\mathrm{n}=19\end{array}$ & $\begin{array}{c}\text { Two } \\
\text { months } \\
\mathrm{n}=32\end{array}$ & $\begin{array}{c}\text { Three } \\
\text { months } \\
\mathrm{n}=15\end{array}$ & $\begin{array}{c}\text { Four } \\
\text { months } \\
\mathrm{n}=16\end{array}$ & $\begin{array}{c}\text { Five } \\
\text { months } \\
\mathrm{n}=19\end{array}$ & & \\
\hline Granary & 11 & 7 & 4 & 3 & 1 & 1 & 2 & 29 & 11 \\
\hline Crib (open) & 3 & 2 & 0 & 1 & 0 & 0 & 0 & 6 & 2 \\
\hline Crib (closed) & 1 & 1 & 0 & 0 & 0 & 2 & 2 & 6 & 2 \\
\hline Basket & 1 & 0 & 0 & 0 & 0 & 0 & 0 & 1 & 0.4 \\
\hline Above fire & 1 & 0 & 0 & 0 & 0 & 0 & 0 & 1 & 0.4 \\
\hline House corner & 5 & 9 & 1 & 4 & 1 & 1 & 3 & 24 & 9 \\
\hline House roof & 2 & 0 & 0 & 0 & 0 & 0 & 0 & 2 & 0.7 \\
\hline Sacks & 63 & 63 & 14 & 24 & 13 & 12 & 12 & 201 & 74 \\
\hline Total & 87 & 82 & 19 & 32 & 15 & 16 & 19 & 270 & \\
\hline$\%$ of total & 32 & 30 & 7 & 12 & 6 & 6 & 7 & & 100 \\
\hline
\end{tabular}

Source: Primary data.

The smallholder farmers who did not sell used all the storage types listed in Table 18. However, the farmers who sold maize did not use baskets, above-the-fire or house roof storage. The farmers who store for increased periods do not use these three types because they are less efficient storage options.

Farmers who stored for sale mainly used house corner, sacks, granaries and cribs as shown in Table 18, with sacks once more the most prevalent storage type. Farmers who stored for three to five months used granaries and open or closed cribs. This finding warrants further investigation to discover which characteristics of these storage types make them preferable for longer storage.

The question arises of whether and how storage types (both preferred and non-preferred) could be improved to increase the storage options for smallholder maize farmers seeking to increase their share of the marketing margin. As Table 18 shows, few farmers store for the more extended periods of time. The chi-square was used to test for association between time of sale and storage type and the finding $(p$-value $=0.360$ ) indicates that there is no significant association between time of sale and the storage type used. This suggests that most farmers may already be optimising their choice of storage, taking into account factors other than time of sale, such as consumption needs and the need to conserve seeds for planting.

\subsection{Analysis of Costs by Storage Type and Time of Sale}

Three types of costs were computed: mean maintenance costs (the costs of maintaining the grain in the storage-for example, chemical costs and repair costs); mean amount lost in storage (an estimate of the grain equivalent lost during the storage period estimated in $\mathrm{kg}$ and converted to a cost by multiplying it by the price of selling maize at harvest time: a measure of the effectiveness of the storage); and mean acquisition cost (the cost of acquiring the storage). These 
three values were computed for the whole sample (those who sold maize, and those who did not), and for the six different times of sale. Figure 2 is a stacked bar graph summarising the results.

Figure 2 shows that the mean maintenance cost was highest (UGX 99,775) amongst smallholder maize farmers using the house corner storage type. This is because in the open environment in the house more chemicals need to be used. The mean maintenance cost for granaries was UGX 87,545, for sacks UGX 44,260, for closed cribs UGX 23,250, for open cribs UGX 5500 and for baskets UGX 5000 with no cost incurred in above the fire and house roof storage. The low maintenance costs of cribs are one aspect of their higher storage effectiveness.

The mean amount of money lost was highest (UGX 379,110) in the house corner storage type, followed by sacks (UGX 249,794) and granaries (UGX 172,528), compared to cribs which incurred losses of UGX 102,800 for closed cribs and UGX 37,050 for open cribs. From this data, the house corner emerges as the least effective storage type while cribs appear to the most effective.

Figure 2 shows that the acquisition costs are highest for closed cribs (UGX $3,750,000$ ), open cribs (UGX 900,000) and granaries (UGX 677,440) while the lowest cost of acquisition is incurred for baskets (UGX 12,000). Figure 2 also shows the different costs incurred for the different storage types against the time of sale or length of storage. The farmers who stored for longest used granaries, open or closed cribs, house corners and sacks. It is surprising that even given its high maintenance cost, the house corner is still used for long storage periods, but it is probable the zero acquisition costs of this storage type present a strong counterbalancing attraction.

This analysis suggests that when considering improvement in storage types, the focus should be on granaries, open or closed cribs, house corners and sacks, all of which are used by those who store the longest. Given that the closed crib is one of the most effective storage types-but has the highest acquisition cost-one direction of improvement could be towards making the closed crib more affordable for resource-constrained smallholder farmers.

Currently, farmers find sacks an attractive storage option. Sacks combine a low acquisition cost (low outlay) and effective storage. However, sacks need to be purchased every year. If the costs of the other types of storage used by farmers are compared to sacks on an annual depreciation cost basis, then they may compare favourably to sacks. Given that, for instance, the closed crib is more effective at storing grain than sacks, as long as the initial outlay can be afforded, the closed crib appears attractive. Thus the affordability and storage effectiveness relationships need to be further explored for the five storage types used by those who stored the longest: granaries, open or closed cribs, house corner and sacks.

\section{Discussion}

The present maize production in Uganda come from a small percentage of arable land and much of the land used is rented. This cattails production capacity 

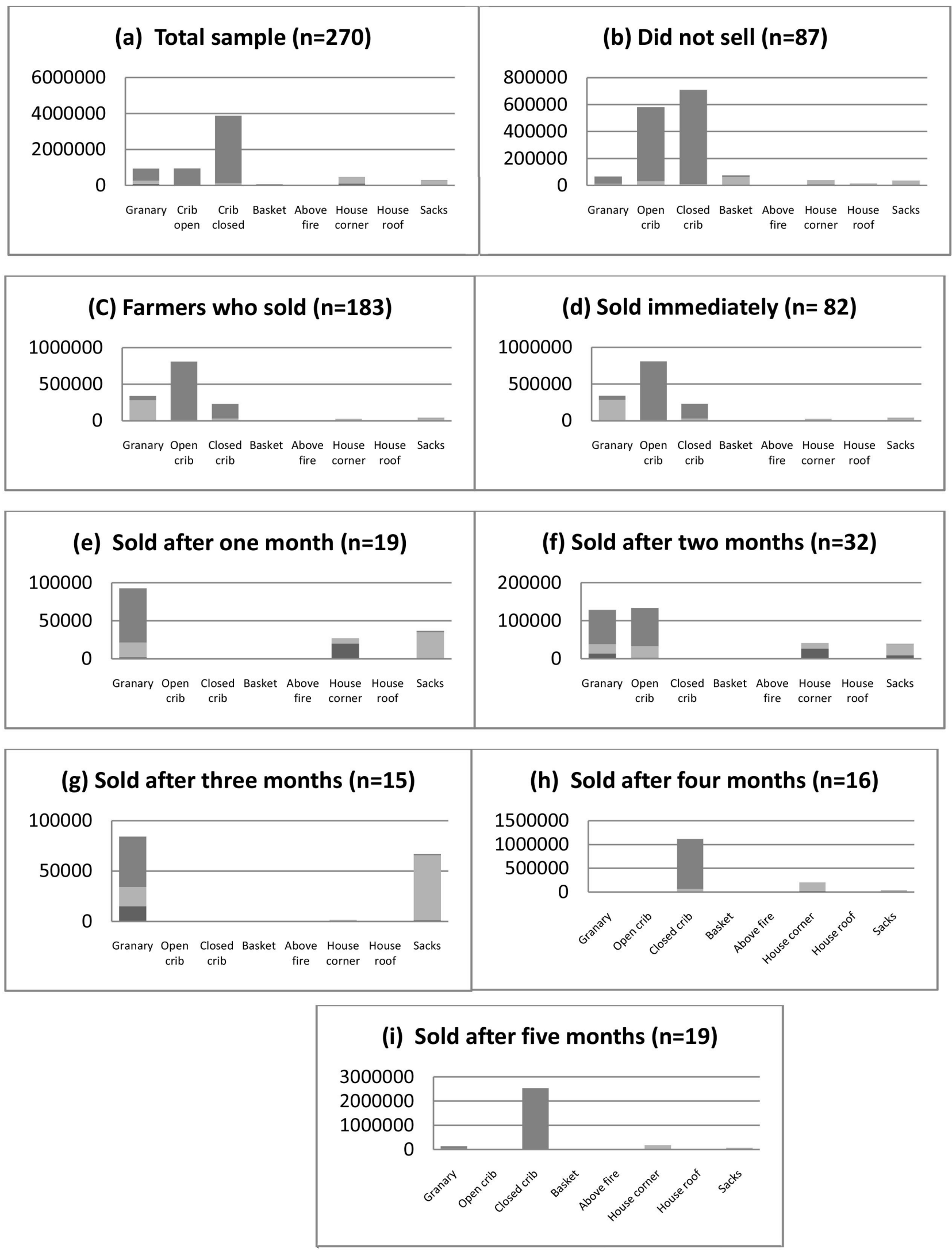

Figure 2. Costs of storage (UGX) by time of sale. (a) to (i): Costs of storage (UGX) by time of sale. Dark Grey: Mean acquisition cost. Grey: Mean loss in storage. Black: Mean maintenance cost. 
and amplifies the reason to store to preclude loss after harvest. Unfortunately currently maize loss in Uganda post-harvest is still high due to the storage types used that are hotspots causing losses. Across all sample districts, sacks were the major storage type and comprised $89 \%$ in Iganga, $76 \%$ in Manafwa and $58 \%$ in Katakwi. Using sacks to store maize has caused a substantial loss to farmers because they are susceptible to damage by insects. These findings may be attributed to the readily available and accessible nature of sacks. Granary storage types were not used in Iganga. Smallholder maize farmers reported that materials for making granaries in Iganga were scarce which made it expensive and that farmers had to outsource the construction as they lacked expertise of making granaries. However, they were used in Manafwa (9\%) and Katakwi (23\%). Smallholder maize farmers reported that baskets were risky to use compared to sacks due to their nature of being wide open and hence less likely to protect the maize from pilferage and pest damage. Generally, the findings show that the choice of storage types differed based on location or district or level of maize growing. Most farmers (62\%) stored for consumption purposes, yet some stored for sale (33\%) and seeds for planting (5\%). Twenty percent of the female farmers were household heads. Household heads made the decision of the storage type to use (50\%), although there were cases when decisions were either reached jointly by household head and spouse (39\%) and in limited circumstance, where a spouse made the decision alone (12\%). Sun drying, red pepper, smoking, ash mixed with water, pesticide fumigation and the use of neem tree leaves (a new innovation) were local methods used for preserving maize in storage.

Generally, market-oriented production depends on system modernization to ensure products reach the market safely [47]. When smallholder maize farmers grow maize they have two major reasons; firstly for consumption and secondly, to sell the surplus. Income and food insecurity for the smallholder maize farmer is caused by inadequate storage which forces the smallholder farmers to sell early when prices are low and to buy in deficit times when prices are high [48]. Due to poor storage at household level, pests, rodents, mould and rats may damage the stored maize. Poor inefficient storage limits smallholder farmers' ability to effectively participate in the maize market because either they do not have the maize to sell or the available maize is of poor quality [47] Moreover, quality is an important determinant of retail price [17]. To circumvent the loss, as a result of quality deterioration in storage, smallholder maize farmers are forced to sell immediately after harvest at a low price, which affects both their food security as they may have to buy maize later and their income security because they sell at a low farm gate price and buy at higher market prices.

Coupled with inadequate storage at household level, smallholder farmers are faced with binding liquidity constraints [18] which also force them to sell immediately after harvest. The immediate sell is associated with economic losses since the prices are normally low due to glut. Thus, farmers are encouraged to store and sell later or use the stored maize to avoid buying later at high prices.

Also, supply and demand for maize are difficult to bring to equilibrium be- 
cause production is still low to meet the demand [46]. This is depicted in the current maize yield in SSA countries of 1.5 tonnes per hectare which is lower than the world average of 4.3 tonnes [46]. Moreover, farmers cannot know with certainty how much they will harvest amidst weather conditions and pest attacks. In view of the mismatch between supply and demand for maize under the smallholder circumstances, one of the immediate solutions appears to be storage because in times of surplus the excess is stored and brought out of the store when there is an increase in demand. Thus, the smallholder farmers with access to reliable storage could increase their share of the marketing margin through selling at a higher price during scarcity and those without maize can buy it locally at a lower price than traders would sell it thus improving both the food and income security of smallholder maize farmers.

\section{Conclusions}

The objective of this study was to identify and characterise the different storage types used by smallholder maize. This study used data from a random sample of 270 respondents from three districts of Iganga, Manafwa and Katakwi. The study provides the following insights: Firstly, it shows that some household characteristics, namely; district (location), gender, acquisition and seasonal use of storage were significantly associated with storage types used. Secondly, smallholder maize farmers use various storage types. It was demonstrated that different farmers used different storage types in different locations or districts. Majority of smallholder maize farmers sold maize immediately after harvest (less than one month). Very few smallholder maize farmers were able to store maize beyond three months, yet storage at household level is important for food and income security. Smallholder maize farmers face difficulty in accessing storage types that are more efficient than the traditional ones. It is important to note that efforts to change smallholder farmers economically, besides focussing on production and productivity of maize, should also be directed towards household level maize storage because it has the potential to alleviate poverty and improve food and income insecurity at household level.

It is important to understand whether, during storage the decision to sell maize continues to be a residual to consumption. It is also important to understand whether, for each household, the store quantities are apportioned to the different uses of consumption, sale and seed. Some storage types are prevalent in particular regions. For instance, it is important to understand why sacks are not as prevalent in Katakwi as in Iganga and Manafwa. This may shed light into how farmers make storage type decisions. This study did not establish if farmers stored the optimal quantities for the desired storage periods. If not what are the factors that precluded that. Finally [1] concluded that "from the policy perspectives, national agricultural development strategies need to guarantee the availability of effective community-based storage infrastructure" (pp 56). We differ with this conclusion because efforts at making storage effective at household, instead of 
community level have not been adequately explored and need to be. Furthermore there is need to establish why sacks are not as prevalent in Katakwi as in Iganga and Manafwa warrants further investigation. Also, there is need to find out why farmers who stored for three to five months used granaries and open or closed cribs.

Further research needs to be conducted to find out other possible ways for smallholder maize farmers can access quick markets to avoid storage. This is because those who sold maize when it was raw got more money. Also an assessment of each storage type in relation to location is critical to identify where each storage should be.

\section{Conflicts of Interest}

The authors declare no conflicts of interest regarding the publication of this paper.

\section{References}

[1] Abass, A.B., Ndunguru, G., Mamiro, P., Alenkhe, B., Mlingi, N. and Bekunda, M. (2014) Post-Harvest Food Losses in a Maize-Based Farming System of Semi-Arid Savannah Area of Tanzania. Journal of Stored Products Research, 57, 49-57. https://doi.org/10.1016/j.jspr.2013.12.004

[2] Shiferaw, B., Prasanna, B.M., Hellin, J. and Bänziger, M. (2011) Crops that Feed the World 6. Past Successes and Future Challenges to the Role Played by Maize in Global Food Security. Food Security, 3, 307-327. https://doi.org/10.1007/s12571-011-0140-5

[3] Omotilewa, O., Ricker-Gilbert, J., Shively, G. and Ainembabazi, H. (2016) The Effects of Risk Perceptions and Liquidity Constraints on the Storage Decisions of Maize and Legume Producers in Uganda. 2016 Annual Meeting, Boston, MA, 31 July-2 August 2016.

[4] Onubuogu, G., Esiobu, N., Nwosu, C. and Okereke, C. (2014) Resource Use Efficiency of Smallholder Cassava Farmers in Owerri Agricultural Zone, Imo State, Nigeria. Scholarly Journal of Agricultural Science, 7, 142-152.

[5] Kaaya, A.N., Warren, H.L., Kyamanywa, S. and Kyamuhangire, W. (2005) The Effect of Delayed Harvest on Moisture Content, Insect Damage, Moulds and Aflatoxin Contamination of Maize in Mayuge District of Uganda. Journal of the Science of Food and Agriculture, 85, 2595-2599. https://doi.org/10.1002/jsfa.2313

[6] Okoboi, G., Muwanga, J. and Mwebaze, T. (2012) Use of Improved Inputs and Its Effect on Maize Yield and Profit in Uganda. African Journal of Food, Agriculture, Nutrition and Development, 12, 1-14.

[7] Sserumaga, J.P., Makumbi, D., Simyung, L., Njoroge, K., Muthomi, J.W., Asea, G., Bomet, D.K., et al. (2015) Incidence and Severity of Potentially Toxigenic Aspergillus Flavus in Maize (Zea mays L.) from Different Major Maize Growing Regions of Uganda. African Journal of Agricultural Research, 10, 1244-1250.

[8] Ferris, R., Engoru, P., Wood, M. and Kaganzi, E. (2006) Evaluation of the Market Information Services in Uganda and Recommendations for the Next Five Years. Contract for PMA/ASPS. Danish Embassy, Kampala, Uganda.

[9] Agona, A., Nabawanuka, J. and Muyinza, H. (2001) An Overview of Maize in Uganda. Post-Harvest Programme, NARO Uganda. 
[10] Gitonga, Z.M., De Groote, H., Kassie, M. and Tefera, T. (2013) Impact of Metal Silos on Households' Maize Storage, Storage Losses and Food Security: An Application of a Propensity Score Matching. Food Policy, 43, 44-55. https://doi.org/10.1016/j.foodpol.2013.08.005

[11] Omotilewa, O.J., Ricker-Gilbert, J., Ainembabazi, H. and Shively, G. (2016) Impacts of Improved Storage Technology among Smallholder Farm Households in Uganda. 2016 Fifth International Conference, Addis Ababa, Ethiopia, 23-26 September 2016, Article ID: 246454.

[12] Atukwase, A., Kaaya, A.N. and Muyanja, C. (2009) Factors Associated with Fumonisin Contamination of Maize in Uganda. Journal of the Science of Food and Agriculture, 89, 2393-2398. https://doi.org/10.1002/jsfa.3734

[13] Montalbano, P., Pietrelli, R. and Salvatici, L. (2017) Market Chain Participation and Food Security: The Case of the Ugandan Maize Farmers, No. 2/17.

[14] Okure, D. and Ssekanyo, S. (2017) User Perception towards a Motorized Thresher ('Kungula') in Uganda: A Need Finding Survey. African Journal of Agricultural Research, 12, 997-1004. https://doi.org/10.5897/AJAR2016.12088

[15] Suleiman, R.A., Rosentrater, K.A. and Bern, C.J. (2013) Effects of Deterioration Parameters on Storage of Maize: A Review. Journal of Natural Sciences Research, 3 , 147.

[16] Affognon, H., Mutungi, C., Sanginga, P. and Borgemeister, C. (2015) Unpacking Postharvest Losses in Sub-Saharan Africa: A Meta-Analysis. World Development, 66, 49-68. https://doi.org/10.1016/j.worlddev.2014.08.002

[17] Thamaga-Chitja, J.M., Hendriks, S.L., Ortmann, G.F. and Green, M. (2004) Impact of Maize Storage on Rural Household Food Security in Northern Kwazulu-Natal. Journal of Family Ecology and Consumer Sciences, 32, 8-15. https://doi.org/10.4314/jfecs.v32i1.52843

[18] Kadjo, D., Ricker-Gilbert, J. and Alexander, C. (2016) Estimating Price Discounts for Low-Quality Maize in sub-Saharan Africa: Evidence from Benin. World Development, 77, 115-128. https://doi.org/10.1016/j.worlddev.2015.08.004

[19] De Groote, H., Kimenju, S.C., Likhayo, P., Kanampiu, F., Tefera, T. and Hellin, J. (2013) Effectiveness of Hermetic Systems in Controlling Maize Storage Pests in Kenya. Journal of Stored Products Research, 53, 27-36. https://doi.org/10.1016/j.jspr.2013.01.001

[20] Kadjo, D., Ricker-Gilbert, J., Alexander, C. and Tahirou, A. (2013) Effects of Storage Losses and Grain Management Practices on Storage: Evidence from Maize Production in Benin. Agricultural and Applied Economics Association 2013 Annual Meeting, Washington DC, 4-8 August 2013.

[21] Shepherd, A. (2012) Grain Storage in Africa: Learning from Past Experiences. Food Chain, 2, 149-163. https://doi.org/10.3362/2046-1887.2012.014

[22] Sun, D., Qiu, H., Bai, J., Liu, H., Lin, G. and Rozelle, S. (2013) Liquidity Constraints and Postharvest Selling Behavior: Evidence from China's Maize Farmers. The Developing Economies, 51, 260-277. https://doi.org/10.1111/deve.12018

[23] Kaminski, J. and Christiaensen, L. (2014) Post-Harvest Loss in Sub-Saharan Africa-What Do Farmers Say? Global Food Security, 3, 149-158. https://doi.org/10.1016/j.gfs.2014.10.002

[24] Fisher, M. and Carr, E.R. (2015) The Influence of Gendered Roles and Responsibilities on the Adoption of Technologies that Mitigate Drought Risk: The Case of Drought-Tolerant Maize Seed in Eastern Uganda. Global Environmental Change, 35, 82-92. https://doi.org/10.1016/j.gloenvcha.2015.08.009 
[25] Latynskiy, E. and Berger, T. (2016) Networks of Rural Producer Organizations in Uganda: What Can be Done to Make Them Work Better? World Development, 78, 572-586. https://doi.org/10.1016/j.worlddev.2015.10.014

[26] Fafchamps, M. and Hill, R.V. (2005) Selling at the Farmgate or Traveling to Market. American Journal of Agricultural Economics, 87, 717-734. https://doi.org/10.1111/j.1467-8276.2005.00758.x

[27] Mugisa, D.J., Katimbo, A., Sempiira, J.E. and Kisaalita, W.S. (2016) Anthropometric Characteristics of Female Smallholder Farmers of Uganda-Toward Design of Labor-Saving Tools. Applied Ergonomics, 54, 177-185. https://doi.org/10.1016/j.apergo.2015.12.010

[28] Green, H., Broun, P., Cakmak, I., Condon, L., Fedoroff, N., Gonzalez-Valero, J., Oniang'o, R.K., et al. (2016) Planting Seeds for the Future of Food. Journal of the Science of Food and Agriculture, 96, 1409-1414. https://doi.org/10.1002/jsfa.7554

[29] Phiiri, G.K., Egeru, A. and Ekwamu, A. (2016) Climate Change and Agriculture Nexus in Sub-Saharan Africa: The Agonizing Reality for Smallholder Farmers. International Journal of Current Research and Review, 8, 57.

[30] Mugabi, R. and Driscoll, R. (2016) Study of Maize Drying in Uganda Using an in-Store Dryer Weather Data Simulation Software. International Journal, 3, 18-26. https://doi.org/10.15379/2408-9826.2016.03.01.03

[31] Kaleta, A. and Górnicki, K. (2013) Criteria of Determination of Safe Grain Storage Time-A Review Advances in Agrophysical Research. InTech Publisher, 295-318. https://doi.org/10.5772/52235

[32] Anastassiadis, F., Feil, J.-H., Musshoff, O. and Schilling, P. (2014) Analysing Farmers' Use of Price Hedging Instruments: An Experimental Approach. Journal of Agricultural \& Food Industrial Organization, 12, 181-192.

[33] Tefera, T., Kanampiu, F., De Groote, H., Hellin, J., Mugo, S., Kimenju, S., Banziger, M., et al. (2011) The Metal Silo: An Effective Grain Storage Technology for Reducing Post-Harvest Insect and Pathogen Losses in Maize While Improving Smallholder Farmers' Food Security in Developing Countries. Crop Protection, 30, 240-245. https://doi.org/10.1016/j.cropro.2010.11.015

[34] Ognakossan, K.E., Affognon, H.D., Mutungi, C.M., Sila, D.N., Midingoyi, S.K.G. and Owino, W.O. (2016) On-Farm Maize Storage Systems and Rodent Postharvest Losses in Six Maize Growing Agro-Ecological Zones of Kenya. Food Security, 8, 1169-1189. https://doi.org/10.1007/s12571-016-0618-2

[35] Proctor, D. (1994) Grain Storage Techniques: Evolution and Trends in Developing Countries. Food \& Agriculture Organization, Rome, Italy.

[36] Baoua, I., Amadou, L., Ousmane, B., Baributsa, D. and Murdock, L. (2014) PICS Bags for Post-Harvest Storage of Maize Grain in West Africa. Journal of Stored Products Research, 58, 20-28. https://doi.org/10.1016/j.jspr.2014.03.001

[37] Kaldor, N. (1939) Speculation and Economic Stability. The Review of Economic Studies, 7, 1-27. https://doi.org/10.2307/2967593

[38] Working, H. (1949) The Theory of Price of Storage. The American Economic Review, 39, 1254-1262.

[39] Brennan, M.J. (1958) The Supply of Storage. The American Economic Review, 48, 50-72. https://doi.org/10.1002/j.1551-8833.1958.tb15627.x

[40] Cifarelli, G. and Paesani, P. (2012) An Assessment of the Theory of Storage: Has the Relationship between Commodity Price Volatility and Market Fundamentals Changed Over Time? Dipartimento do Scienze Economiche Universita degli Studi 
de Firenze Working Paper No. 12. https://doi.org/10.2139/ssrn.2075514

[41] Gorton, G.B., Hayashi, F. and Rouwenhorst, K.G. (2012) The Fundamentals of Commodity Futures returns. Review of Finance, 17, 35-105. https://doi.org/10.1093/rof/rfs019

[42] Chalotra, V. (2013) Inventory Management and Small Firms Growth: An Analytical Study in Supply Chain. Vision: The Journal of Business Perspective, 17, 213-222. https://doi.org/10.1177/0972262913496726

[43] Botterud, A., Kristiansen, T. and Ilic, M.D. (2010) The Relationship between Spot and Futures Prices in the Nord Pool Electricity Market. Energy Economics, 32, 967-978. https://doi.org/10.1016/j.eneco.2009.11.009

[44] Kagoda, F., Gidoi, R. and Isabirye, B.E. (2016) Status of Maize Lethal Necrosis in Eastern Uganda. African Journal of Agricultural Research, 11, 652-660. https://doi.org/10.5897/AJAR2015.10616

[45] Midega, C.A., Murage, A.W., Pittchar, J.O. and Khan, Z.R. (2016) Managing Storage Pests of Maize: Farmers' Knowledge, Perceptions and Practices in Western Kenya. Crop Protection, 90, 142-149. https://doi.org/10.1016/j.cropro.2016.08.033

[46] Oo, N.P. (2016) Analysis of Risk Management Practices among Maize Based Farmers in Abia State, Nigeria. Asian Economic and Financial Review, 6, 490-498. https://doi.org/10.18488/journal.aefr/2016.6.8/102.8.490.498

[47] Omiti, J., Otieno, D., Nyanamba, T. and McCullough, E. (2009) Factors Influencing the Intensity of Market Participation by Smallholder Farmers: A Case Study of Rural and Peri-Urban Areas of Kenya. African Journal of Agricultural and Resource Economics, 3, 57-82.

[48] Stephens, E.C. and Barrett, C.B. (2011) Incomplete Credit Markets and Commodity Marketing Behaviour. Journal of Agricultural Economics, 62, 1-24. https://doi.org/10.1111/j.1477-9552.2010.00274.x 